\title{
The Relationship between Dividend Policy and Shareholder's Wealth (A Case Study At Mining Companies in Indonesia)
}

\author{
Riska Yustisiana \\ (Fakultas Ekonomi \& Bisnis, University of Pancasila, Indonesia)
}

\begin{abstract}
This research is about the relationship between dividend policy and shareholder's wealth from 37 mining companies listed in Indonesia Stock Exchange (IDX) from 2011 to 2013. Independent variable which is used in this research are dividend policy and profitability. Dividend policy is measured as dividend per share (DPS) and profitability is measured as Return On Equity (ROE). Dependent variable which is used in this research is shareholder's wealth. Shareholders' wealth is measured as Market Price Per Share (MPPS). Investment opportunity which is measured as fixed asset growth, is used as moderating variable which can strengthen the relationship between independent and dependent variable. The result of this research proves that dividend policy has significant influence to shareholder's wealth, while investment opportunity, as a moderating variable, is proven to strengthen the relationship between dividend policy and shareholder's wealth.
\end{abstract}

Keywords: Dividend Policy, Investment opportunity, ROE, Shareholder's Wealth

\section{Introduction}

Various factors can be used as a consideration on making investment decision. Macroeconomic indicators such as economic growth, gross domestic product, and inflation can be used by Indonesian investors on making investment decision. In second quarter of 2016, Indonesia's economic growth rate is approximately $5,18 \%$. Gross domestic product (GDP) increases about 4,02\% compared to the first quarter. Indonesia's economic growth decreases as well as the world does, but when it is compared with another region countries including developed countries in South East Asia, Indonesia's economic growth is higher. According to BPS (Badan Pusat Statistik), Indonesia's inflation rate is 3,35\% in 2015 and 2,11\% in 2016 until October 2016. In this case, inflation rate is lower than Indonesia's economic growth. From various factors of macroeconomic perspectives above, Indonesia's economic growth is relatively in a good condition. This condition is proved by good banking condition and banking liquidity which is shown by low NPL (Non Performing Loan) under 3\%.

Indonesia Composite Index (IHSG) between January until October 2016 is stable in level IDR 5.100. Indonesia composite index (IHSG) also reacts along with Trump's election as US President. For investor, that should be the perfect time to do a new investment. Positive growth of Indonesia Composite Index (IHSG) and Indonesia's economic condition can make a perfect investment return in the future. Besides macroeconomics factors and positive movement of Indonesia Composite Index (IHSG), investor's preferences are also influenced by company's policy. Company dividend policy is one of the reasons for investors to buy the stocks. Dividend policy determines how company's profit is shared and distributed to investors as a dividend. In Indonesia, like other investors in developed countries with low tax rate, the investors prefer a company which allows company's profits that can be shared and distributed as a dividend better than as retained earnings. Companies with higher dividend rate are preferred by the investors, that can increase the stock market price. The increasing of stock price shows a positive return for the investors return that can increase shareholder's wealth. The investor's decisions are also influenced by company's good profits track record so, it will attract more investors to buy the stocks. Investment opportunity is also affect the increasing of company's stock price. Company with a great investment opportunity has a potential to have positive growth in the future.

The purpose of this research is to know the relationship between dividend policy and company's profitability with shareholder's wealth. Dividend policy is measured as dividend per share (DPS), company's profitability is measured as return on equity (ROE), and shareholder's wealth is measured as market price per share (MPPS). Investment opportunity which is measured as fixed asset growth, is a moderating variable to strengthen the relationship between independent and dependent variables.This research is taken on mining companies listed in Indonesia Stock Exchange (IDX). Indonesian Regulation, Act Number 4 Year 2009 About Mineral and Coal Mining, which controls mineral and coal mining, prohibits raw mining material export since 2014. Mining company must obligate that regulation by building a smelter. Smelter is used to process and purify raw mining material into final mining material. Those regulations can affect the company's dividend policy. They need huge amount of investment to build the smelter. Moreover, the company must give more portions of their profit to invest in smelter building. On the other hand, their profit must be shared with the shareholders. This mean, the shareholders will only receive less than it should be. Therefore, this research will elaborate the impact of those regulations to company's dividend policy. The period of this research is from 2011 to 2013. 


\section{Literature Review}

There were three fundamental theories about dividend policy based on investor's preferences (Brigham and Daves, 2004): 1) Dividend Irrelevance Theory. In this theory, dividend policy didn't influence company's stock price and its capital. Company's value was only determined by their ability to make profits. According to Modigliani Miller, if company didn't share the dividend, a shareholder could get their dividend on cash by selling their stock. Otherwise, if company shared the dividend, but shareholder didn't want the dividend on cash, they could use it to buy more stocks. 2) Bird-in-the-Hand theory. This theory said that company value would be maximizes by sharing the high dividend. In this theory, Companies which shared high amount of their dividend to shareholders would get positive response from the shareholders who preferred cash dividend. This would make company's stock price and value increased because the shareholders would buy more stocks form the company. 3) Tax Preference Theory. This theory explained that company's value and stock would increase if company shared less amount or not share the dividend because there were high tax rate for its dividend. Because of the high tax rate, investors were less interested with company which shared high amount of dividend. In this case, less amount of dividend was preferred by the investors.

According to Brigham and Daves (2004), when Modigliani Miller (MM) talked about the irrelevance dividend theory, they assumed that every investor had same information about revenue and dividend in the future. However in reality, investor had different information about dividend share in the future and uncertainty on that dividend share, but the management of the company had a better information about it better than them. Increasing dividend also often generated higher stock price, meanwhile decreasing dividend often led lower stock price. For the investor, the higher dividend indicates that the company would get greater profits in the future. Meanwhile the lower dividend indicated that the company would get less profit in the future. Modigliani Miller said that investor's reaction toward the changes of dividend policy did not show that they choose shared dividend better than retained earnings, whereas they indicated that stock price changes after dividend was shared only showed some important information in that dividend.

Shareholders were company's owner. They bought company's stocks to get return and profits for their invested capital (Brigham and Daves, 2004). Shareholders have authority to select the board of director. And board of director will continue to assign the managers to run daily activity in the company. Managers must provide some programs and strategies to increase company's value for the shareholders. Therefore, the main purpose of the company was to optimize shareholder's wealth by increasing stock price. If stock price was increase, the invested capital in the company would increase as well as the shareholder's wealth. In this research, shareholder's wealth is defined by market price per share (MPPS). There were some related research which had been done by others about company's dividend policy. Since 1978, stock price tendency was decreased as a reaction from shared dividend announcement in US (Amihud and Li, 2003). There were positive and significant relationship between cash dividend, retained earnings, EPS, and stock price (Asep and tian, 2010). There was strong relationship between dividend policy and company stock price, while other variables didn't have any relation with company dividend policy (Asyar and Hamid, 2011).

Company's policy had a positive relationship with organizational profit, investment, and EPS (Adediran and alade, 2013). Altaraireh and Jordan (2012) found that there was also positive relationship between dividend, cash flow, EBIT, EPS, dividend yield, and firm size. On the other hand, there were negative relationship between dividend and debt ratio. Large company would get more dividend policy effects than small company. Gul et al (2012) studied about the impact of dividend policy to shareholders wealth. They founded that there were some differences about average market value and equity value between company that share their dividend and company that retained their earning. Retained earnings and Price Earnings Ratio (PER) did not have significant influence on shareholder's wealth. Dividend policy had positive and significant influence on shareholders' wealth.

Baker et al (2006) said that company's value and shareholders' wealth were clearly influenced by company's dividend policy. Moreover, Aminu and Abor (2006) said that large profit companies in Ghana would give high portion of dividend to the shareholders. Dewi (2008) had some research about the effect of managerial ownership, institutional ownership, loan policy, profitability, and company's size to dividend policy. She founded that all of those variables had negative impact to company's dividend policy. Al-hasan et al (2013) told that dividend policy had more influences to the stock price than retained earnings. Furthermore, Murhadi (2008) found that company which shared its dividend to shareholders had more liquid in capital stock market than the company which not shared its dividend to shareholders. Hasnawati (2005) did some research to 259 public companies which were listed in Indonesia Stock Exchange (IDX). Her research was about the relationship between investment opportunity and company value. She said that investment decision had 12,25\% positive influence for the company and the rest of it were influenced by other factors such as, funding policy, divident policy, and macroeconomic conditions. Suharli (2007) studied about the influence of ROI and investment opportunities to dividend policy with current ratio as a moderating variable. It was founded that dividend policy was only affected by profitabilities. Hutami (2012) found that profitability ratio, ROE, DPS, and NPM had a 
positive and significant influence to stock price of manufacture industries. In addition, Ansar, Butt, and Shah (2015) found that there were strong relationship between shareholder's wealth and dividend policy. Shareholder's wealth would increase along side with dividend policy. Furthermore Maksum (2014) said that EPS, retention ratio, and return on equity (ROE) had positive relationship with stock market price which affect shareholders' wealth.

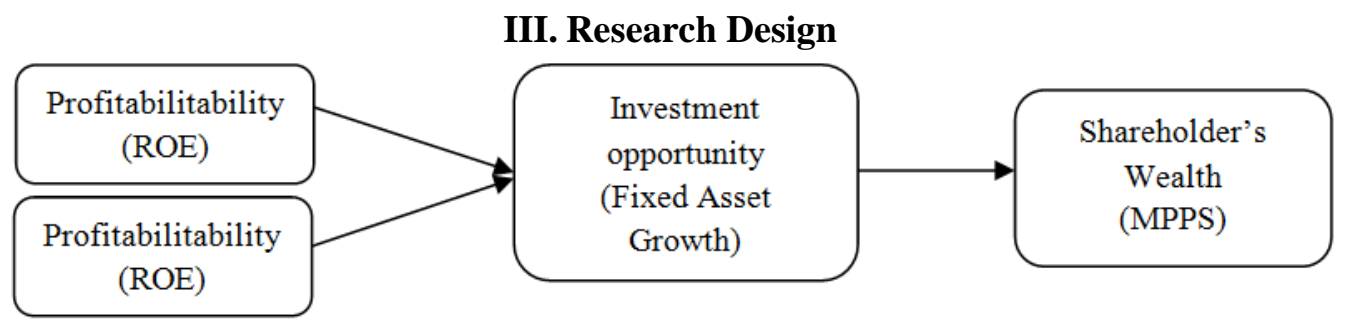

\section{Hypothesis}

From the previous research and theories above, there is the hypothesis:

H1: Dividend Per Share (DPS) has significant impact on Market Price Per Share (MPPS)

H2: Return On Equity (ROE) has significant impact on Market Price Per Share (MPPS)

H3A: Investment Opportunity (Fixed asset growth) strengthen the relationship between Dividend Per Share (DPS) and Market Price Per Share (MPPS)

H3B : Investment Opportunity strengthen the relationship between Return On Equity (ROE) and Market Price Per Share (MPPS)

H4 : Dividend Per Share (DPS) and Return On Equity (ROE) have significant impact on Market Price Per Share (MPPS)

Based on previous researches, theories, and research framework, these are the summary of research variable measurement:

Research Variable Measurement

\begin{tabular}{|c|c|c|c|}
\hline No & Variable & Proxy & Variable measurement \\
\hline 1. & Shareholder's Wealth & Market Price Per Share (MPPS) & Stock price per share \\
\hline 2. & Dividend Policy & Dividend Per Share (DPS) & DPS $=\frac{\text { Common Stock dividend }}{\text { Outstanding Shares }}$ \\
\hline 3. & Profitability & Return On equity (ROE) & ROE $=\frac{\text { Net Profit }}{\text { Total Equity }}$ \\
\hline 4. & Investment opportunity & Fixed Asset Growth & $\begin{array}{l}\Delta \text { Fixed asset }=(\text { Fixed asset } t-\text { Fixed } \\
\text { asset }_{\mathrm{t}-1)} / \text { Fixed asset }{ }_{\mathrm{t}-1}\end{array}$ \\
\hline
\end{tabular}

\section{Research Finding}

Independent variables in this research are dividend policy measured by dividend per share (DPS) and profitability measured by return of equity (ROE). Moderating variable in this research is investment opportunity measured by fixed asset growth. Dependent variable is shareholder's wealth measured by market price per share (MPPS).Populations in this research were all companies' stock that was listed in Indonesia Stock Exchange (IDX). Sample in this research are mining companies which also listed in Indonesia Stock Exchange (IDX). The period of this research was from 2011, 2012, and 2013. This research used secondary data such as dividend per share (DPS), ROE, investment opportunity (fixed asset growth), and MPPS. The data were collected from company's financial report and market data from 37 mining companies which were obtained from yahoo.finance.com and Indonesia Stock Exchange (IDX) website. This research use regression analysis equation such as:

MPPS $=\alpha 1+\beta 1$ DPS $+\beta 2 \mathrm{ROE}+\mathrm{e}$

Note:

MPPS = Market Price Per Share (MPPS)

DPS $\quad=$ Dividend Per Share (DPS)

ROE $\quad=$ Return On equity (ROE)

$\alpha \quad=$ Constant term of the model

$\beta 1, \beta 2=$ Coefficients of the model

Meanwhile when investment opportunity is inserted as moderating variable, the equation will be:

MPPS $=\alpha 2+\beta 3$ DPS $+\beta 4$ IO $+\beta 5$ Moderate $+\mathrm{e}$

MPPS $=\alpha 2+\beta 3 \mathrm{ROE}+\beta 4 \mathrm{IO}+\beta 5$ Moderate $+\mathrm{e}$ 
The Relationship between Dividend Policy and Shareholder's Wealth (A Case Study At Mining...

Note:

MPPS = Market Price Per Share (MPPS)

DPS = Dividend Per Share (DPS)

$\mathrm{ROE}=$ Return On equity (ROE)

IO = Investment Opportunity

$\alpha \quad=$ Constant term of the model

$\beta 3, \beta 4, \beta 5=$ Coefficients of the model

1.1. Descriptive statistics

This research used 111 data. Those data were from 37 mining companies since 2011 until 2013.

\section{Descriptive Statistics}

\begin{tabular}{|l|l|l|l|l|l|l|}
\hline & DPS & INVGR & MODRDPS & MODROE & MPPS & ROE \\
\hline Mean & 165.5766 & 66.92885 & 23.70395 & 610.8039 & 3462.545 & 9.732891 \\
\hline Median & 0.000000 & 0.230960 & 0.000000 & 1.401930 & 1176.250 & 8.750000 \\
\hline Maximum & 14233.00 & 5539.339 & 554.9524 & 52789.90 & 44258.33 & 213.7900 \\
\hline Minimum & 0.000000 & -0.994707 & -0.009591 & -156.4381 & 50.00000 & -161.9300 \\
\hline Std. Dev. & 1354.679 & 540.8159 & 84.61251 & 5181.823 & 7572.464 & 38.66155 \\
\hline Observations & 111 & 111 & 111 & 111 & 111 & 111 \\
\hline
\end{tabular}

Based on the table above, average dividend per share (DPS) of mining companies was Rp 165,58 and average value of Market Price per Share (MPPS) of mining companies were Rp 3.462.

\subsection{Classic Assumption Test}

This research used multikolinearities test and heterokesdasities test. Multikolinearities test used pair wise correlation. The methode was done by looking the correlation from all variables that be found on this research and it would be made in to a matrix. The matrix's value was one or closer to one, there were multikolinearities between those independent variables. From regression analysis, the highest value between independent variables was 0.5 . So that, there was no multikoliniearities between all the independent variables. Heterokesdasities test was done to identify error term in the equation. If the error term was heterokedasities, then the regression result was no longer BLUE (Best, Linear, Unbiased, and Estimator). From the test above, there was heterokesdasities in the data. Therefore the data should be corrected by doing valuation quality to the data.

\subsection{Regression analysis}

Regression analysis result is shown on this table below:

\section{Regression Result}

\begin{tabular}{|l|l|l|l|l|}
\hline Variable & Coefficient & Std. Error & t-Statistic & Prob. \\
\hline C & 2178.868 & 623.4676 & 3.494758 & 0.0007 \\
\hline DPS & 1.278058 & 0.573353 & 2.229095 & 0.0279 \\
\hline ROE & 26.14074 & 15.28050 & 1.710726 & 0.0901 \\
\hline MODDPS & 35.43545 & 9.236814 & 3.836329 & 0.0002 \\
\hline MODROE & -0.036550 & 0.112907 & -0.323720 & 0.7468 \\
\hline R-squared & 0.368207 & \multicolumn{4}{|l}{} \\
\hline Adjusted R-squared & 0.344366 & \multicolumn{4}{|l|}{} \\
\hline
\end{tabular}

From the table above, variable which has significant influence to shareholder's wealth was dividend per share (DPS) either it stands alone or be moderated by investment opportunity (fixed asset growth). Dividend per share (DPS) positively influenced shareholder's wealth. Increasing dividend would cause market price per share (MPPS) increase 1,278 point. That indicate, if dividend increase $1 \%$ would cause market price per share (MPPS) increase 1,278 point. However, if dividend per share (DPS) was moderated by fixed asset growth, it would positively affect market price per share (MPPS). Increasing of $1 \%$ moderating variable would cause market price per share (MPPS) escalate 35,43 point. Investment opportunity (fixed asset growth) strengthens the relationship between dividend policy and shareholder's wealth. Company decision to add more fixed asset would make stock price increased in the stock market. Therefore, fixed asset growth and dividend per share (DPS) would give positive influence in stock market, especially for mining company. 
The conclusions in this research are:

\section{Conclusion \& Suggestion}

1. The research data can represent the real condition with $\mathrm{R}$ squared value $36,82 \%$.

2. Dividend per share (DPS) which is moderated by investment opportunity (fixed asset growth) has positive influence to market price per share (MPPS) of mining companies which is listed in Indonesia Stock Exchange (IDX) between 2011 and 2013. Fixed asset growth strengthen the positive relationship between dividend per share (DPS) and market price per share (MPPS).

\section{Suggestions for this research are:}

1. Dividend per share (DPS) significantly affect market price per share (MPPS). Company should be careful on applying dividend policy or adding more fixed asset.

2. In the next research, there should be more variables used (not only dividend per share and market price per share) which can give significant effect to the stock price (market price per share).

3. The research should be done in long term research because the exporting raw material regulation must be obligated by all mining company not more than 2014 .

\section{References}

[1]. Brigham. E.F, and Daves. P.R, Intermediate Financial Management (South-Western Publishing, 2004)

[2]. Amihud. Y, and Li. K, The Declining Information Content of Dividend Announcements and the Effect of Institutional Holdings, Journal of Financial and Quantitative Analysis, 2003

[3]. Asem. E, and Tian. G.Y, Market Dynamics and Momentum Profits. Journal of Financial and Quantitative Analysis,45(06), 2010, pp.1549-1562. Available at: http://www.journals.cambridge.org/abstract_S0022109010000542.

[4]. Adediran. S, and Alade. S.O, Dividend Policy and Corporate Performance in Nigeria, American Journal of Social And Management Sciences, 2013, pp.71-77.

[5]. Altaraireh. J.A, and Jordan. P.U, A Worthy Factors Affecting Dividends Policy Decisions: An Empirical Study On Industrial Corporations Listed In Amman, Interdisciplinary Journal of Contemporary Research in Business, 2012, pp.614-622.

[6]. Gul. S. et al, The Relationship Between Dividend Policy and Shareholder 's Wealth (Evidence from Pakistan) , 2(2), 2012, pp.5559.

[7]. Baker. H.K, Mukherjee. T.K, and Paskelian. O.G, How Norwegian Managers View Dividend Policy. Global Finance Journal, 17(1), 2006, pp.155-176.

[8]. Amidu. M, and Abor. J, Determinants of Dividend Payout Ratios in Ghana, The Journal of Risk Finance, 7(2), 2006, pp.136-145.

[9]. Dewi. Sisca. C, Pengaruh Kepemilikan Manajerial, Kepemilikan Institusional, Kebijakan Hutang, Profitabilitas dan Ukuran Perusahaan Terhadap Kebijakan Dividen, Jurnal Bisnis dan Akuntansi Vol 10 No. 1, 2008, pp. 47- 58

[10]. Al-Hasan. M, Asaduzzaman. M, and Karim. R. Al, The Effect of Dividend Policy on Share Price: An Evaluative Study, Iosrjournals.Org, 1(4), 2013, pp.6-11. Available at: http://www.iosrjournals.org/iosr-jef/papers/vol1-issue4/B0140611.pdf.

[11]. Murhadi. W.R, Study On Dividend Policy: Antecedent and Its Impact On Share Price, Munich Personal Repec Archive, (1956), 2008, pp.1-29.

[12]. Hasnawati. S, Dampak Set Peluang Investasi Terhadap Nilai Perusahaan Publik di Bursa Efek Jakarta. JAAI, 9, 2005, pp.117-126.

[13]. Suharli. Michell, Pengaruh Profitability, Investment Opportunity Set, Terhadap Kebijakan Dividen Tunai Dengan Likuiditas Sebagai Variabel Penguat (Studi Pada Perusahaan Terdaftar di Bursa Efek Jakarta Periode 2002-2003). Jurnal Akuntansi dan Keuangan Vol 9 No 1, 2007, pp. 9-17.

[14]. Hutami. R. Putri, Pengaruh Dividend Per Share, Return on Equity, dan Net Profit Margin Terhadap Harga Saham Perusahaan Industri Manufaktur Yang Tercatat Di Bursa Efek Indonesia Periode 2006-2010, Jurnal Nominal Volume I Nomor I, 2012.

[15]. Ansar, Butt, and Shah, Impact of Dividend Policy on Shareholder's Wealth, International Review of Management and Business Research, Vol 4 Issue 1, March 2015.

[16]. Maksum. Abdullah Al, 2014. Dividend Policy and Its Impact on Stock Price - A Study on Commercial Banks Listed in Dhaka Stock Exchange, Global Disclosure of Economics and Business, Volume 3, No 1 ,2014

[17]. www.idx.co.id

[18]. www.yahoo.finance.com 